This is a preprint version. The accepted paper to be published in the Journal of Cleaner Production is available at: http://dx.doi.org/10.1016/i.jclepro.2016.10.163

Citation : Mihai F-C, Ingrao C, Assessment of biowaste losses through unsound waste management practices in rural areas and the role of home composting, Journal of Cleaner Production(2016), doi: 10.1016/j.jclepro.2016.10.163.

\title{
Assessment of biowaste losses through unsound waste management practices in rural areas and the role of home composting
}

\author{
${\text { Florin-Constantin } \text { Mihai }^{l^{*}} \text {, Carlo Ingrao }}^{2}$ \\ ${ }^{1}$ Department of Geography, “Alexandru Ioan Cuza” University of Iasi, Romania, B-dul Carol I, Nr. 20 A, \\ RO-700505, Iasi, Romania \\ ${ }^{2}$ Department of Economics, University of Foggia, Via Romolo Caggese, 1 - 71121 Foggia, Italy \\ *corresponding author : mihai.florinconstantin@gmail.com
}

\begin{abstract}
The paper examines the biowaste management issues across rural areas of Romania in the context of poor waste management infrastructure in the last decade (2003-2012). Biowaste is the main fraction of municipal waste, thus a proper management is a key challenge in order to sustain a bioeconomy in the near future. The amount of biowaste generated and uncollected by waste operators is generally uncontrolled disposed if not recovered through home composting. The paper points out the role of home composting in diverting the biowaste from wild dumps and landfills for the regions covered or not by waste collection services. Home composting and the biowaste losses are further assessed based on several scenarios (worse-case, pessimistic, realistic, optimistic) where the net loads of greenhouse gasses (GHG) are calculated at national and regional levels. The transition of home composting techniques, from open piles to plastic bins with respect to standard guidelines will improve the home composting performance in terms of compost quality and net GHG's savings, supporting a bio-based economy which will lead towards a sustainable rural development. Regional disparities are revealed across Romanian counties and the paper opens new research perspectives regarding which options should be adopted by counties and rural municipalities in the biowaste management process.
\end{abstract}

Keywords: home composting, biowaste, rural areas, waste management; GHG's emissions

\section{Introduction}

Sustainable production and consumption are key challenges to maintain an equilibrium of Earth systems. This emphasizes upon the urgent need for socio-economical disparities between highincome and developing countries or urban and rural areas to be mitigated to achieve a global, sustainable future. As documented by Blok et al. (2015), sustainable production pathways imply 
eco-efficiency, waste reduction and the use of renewable resources. Amongst those currently available, biomass is a crucial renewable resource with a wide geographical coverage that could be used in multiple eco-friendly ways by both the industrialized and emerging economies.

Both improvements and innovations in cleaner ways of biomass production and processing could be one way to favor the transition to post-carbon fossil societies at the global scale. Biomass plays a key role in order to develop bioeconomies across EU (Scarlat et al. 2015) and, so, support sustainable growth pathways (European Commission, 2012).

Romania has released the first master plan for biomass management, which points out the potential role of biomass in complying EU regulations regarding the use of renewable energy source in 2020 (Ministery of Economy and Commerce, 2010). In Romania, biomass represents a promising renewable energy source (Scarlat et al. 2011), including the organic fraction of the municipal solid waste stream (Ciubota et al. 2008). Sustainable waste management is considered important for optimizing the use of biomass in the bioeconomy (Besi and McCormick, 2015). A sound biowaste management is a promising solution towards post-fossil carbon societies.

Biowaste is a major fraction of the municipal waste stream, particularly in rural areas of transition and developing countries. Traditional recovery of biowaste through home composting and animal feed has diverted such fraction from local environmental pollution since preindustrial times. Currently, biowaste streams are fed by domestic, industrial and agricultural sectors with unsustainable ways of utilizing and processing them. The increasing waste amounts demand more attention to the waste management sector. A mix of cleaner and innovative technologies with best traditional practices will provide the transition towards societies that are based upon efficient, sustainable ways of managing natural resources. The EU policy supports the waste reduction, recycling and recovery activities under the waste hierarchy concept and circular economy framework. Companies are increasingly being required to seek for, develop and promote innovative solutions and strategies to transform boost invaluable by-products under the circular economy framework. Governance, strength, alignment and complimentary resources are important drivers for biomass valorization at company level, as shown by Wubben et al. (2012). The biowaste should be regarded as a material recovery or energy source which may help rural communities to achieve a sustainable rural development. Home composting is more practical and economically viable if a source-segregation of biowaste is performed and if critical parameters are properly managed (Van-Fan, 2016).

This paper examines the biowaste management issues across rural areas of a new EU Member in the context of poor coverage of waste management services in the last decade (2003-2012). The paper reveals the geographical dimension of biowaste losses across Romanian counties through unsound waste disposal practices. The paper aims to highlight the crucial role of home composting in the recovery process of this fraction.

Home composting is an environmentally sustainable solution across rural areas, but good practice is highly required among inhabitants. A proper home composting procedure will increase the quality of compost, the agricultural productivity of land with less impact on the environment, consolidating a bio-based economy in rural areas. 


\section{Materials and Methods}

\subsection{Literature review}

Waste collection services (WCS) are frequently performed only for rural communities in the proximity of major cities, and large rural regions are usually not covered by waste operators. Wild dumps, river dumping or open burning of household waste are the improper disposal options adopted by rural communities (Mihai, 2012). Such bad practices represent a threatening factor for both public health and the local environment and cause significant losses in terms of composting, recycling or energy recovery potential. Home composting is a suitable treatment option for organic wastes such leftovers of raw fruit and vegetables from the technical and environmental point of view, as documented by Colon et al. (2010). Composting, biomass fuel production, and anaerobic digestion contributes to GHG emission savings, and so they sound as valid alternatives to be considered for biowaste treatment (Ortner et al. 2013).

Andersen et al. (2010) found that GHG emission of home composting units (cone-shaped, made of recycled polyethylene and polypropylene) is similar in magnitude as for centralized composting plants in Denmark. In Sweden, over 50000 tons of food waste is used for home composting where GHG's emissions are lower than in studies on large-scale composts (Ermolaev et al., 2014). Home composting (backyard or individual composting) is mainly developed at the household and/or small-farm scale where the compost produced is utilized as a natural fertilizer.

According to Smith and Jasim (2009), home composting has good results also in urban areas where households own vegetable gardens. Home composting is not always performed in an organized manner (frequently open piles) across rural Romania as suggested by local environmental authorities. Such causes reduction of both compost quality and $\mathrm{CO}_{2}$-emission savings. New EU members are working to find new solutions to solve such problems and to avoid the landfill of biowaste. Such efforts were highlighted by Havukainen et al. (2012) in Lithuania; Barekova et al. (2013) in Slovakia; Horsák and Hřebíček (2014) in Czech Republic; Stanic-Maruna and Fellner (2012) in Croatia and Wójcik et al. (2014) in Poland. At the household level, composting and vermicomposting are clean, sustainable and affordable technologies because they reuse waste to produce organic fertilizer supporting the local agriculture (Lim et al. 2016).

In rural regions, as mainly characterized by sparse settlements where households own gardens, home composting is more practicable and cost-efficient option. Traditional recovery of household waste includes home composting, animal feed, and reuse of other fractions like, for instance, wood \& paper fractions for household heating, glass bottles for food provisions. Such practices encourage the waste prevention and waste diversion from wild dumps with the related environmental impacts and emissions savings which are further investigated. 
2.2 Estimations of biowaste generated and uncollected

The paper estimates the amounts of biowaste of total waste generated and uncollected in rural areas which are managed at household level or improperly disposed. These calculations are determined based on rural population unserved (nr.of inhabitants) by waste collection services (WCS) and on the other hand, by rural municipal waste composition at NUTS 2 scale (nomenclature of territorial units for statistic: http://ec.europa.eu/eurostat/web/nuts/overview) provided by regional waste management plans for 2003 and Ciuta et al.(2015) for 2012.

The amounts of bio-waste generated and uncollected is determined as:

$\mathrm{Q}_{\mathrm{bwu}}\left(\mathrm{t} . \mathrm{yr}^{-1}\right)=\mathrm{P}_{\mathrm{nowCS}} * \mathrm{G}_{\mathrm{rw}} * 365 / 1000 * \mathrm{~S}_{\mathrm{bwr}}(\%)$

where:

- $\quad \mathrm{Q}_{\mathrm{bwu}}=$ amount of biowaste generated and uncollected by waste operators (t.yr $\left.{ }^{-1}\right)$

- $\mathrm{P}_{\text {noWCS }}=$ number of inhabitants with no access to WCS

- $\mathrm{G}_{\mathrm{rw}}=$ per-capita waste generation rate in rural areas $\left(\mathrm{kg}\right.$. inhab.day $\left.{ }^{-1}\right)$

- $\mathrm{S}_{\mathrm{bwr}}(\%)=$ the share of biowaste in the total municipal waste composition (regional data) The national per-capita waste generation rates specific to rural areas are used due to the lack of

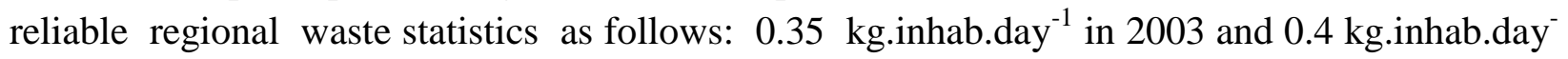
${ }^{1}$ in 2012. Ciuta et al.(2015) reveals rural waste generation averages at the NUTS-2 level with values which vary between $0.31 \mathrm{~kg}$. inhab.day $^{-1}$ in North-East Region to $0.66 \mathrm{~kg}$.inhab.day ${ }^{-1}$ in Bucharest-Ilfov Region. Such regional data are important in order to outline the regional disparities across the country. These regional data are used for 2012 as opposite to the national rate stipulated in waste management plans $\left(0.4 \mathrm{~kg}\right.$.inhab.day $\left.{ }^{-1}\right)$. It seems that the national flat rate overestimates the amount of biowaste generated and uncollected $\left(\mathrm{Q}_{\mathrm{bwu}}=555.53 \mathrm{kt}\right)$ compared to regional averages $\left(\mathrm{Q}_{\mathrm{bwu}}=490.2 \mathrm{kt}\right)$. The difference of $65.33 \mathrm{kt}$ points out the necessity to develop reliable regional waste statistics in Romania. The regional waste composition data (2003) provided by regional waste management plans (2006) are specific to rural areas based on local waste operators estimations. Ciuta et al. (2015) performed experimental studies for Sercaia commune (Brasov county, Center Region), but the municipal waste composition data computed are specific only for regional level. Such data are not broken down into urban and rural areas as per-capita waste generation rates. The biowaste generated and uncollected was determined using the regional shares of biowaste in the total municipal solid waste (MSW) fraction shown in Fig.1. 


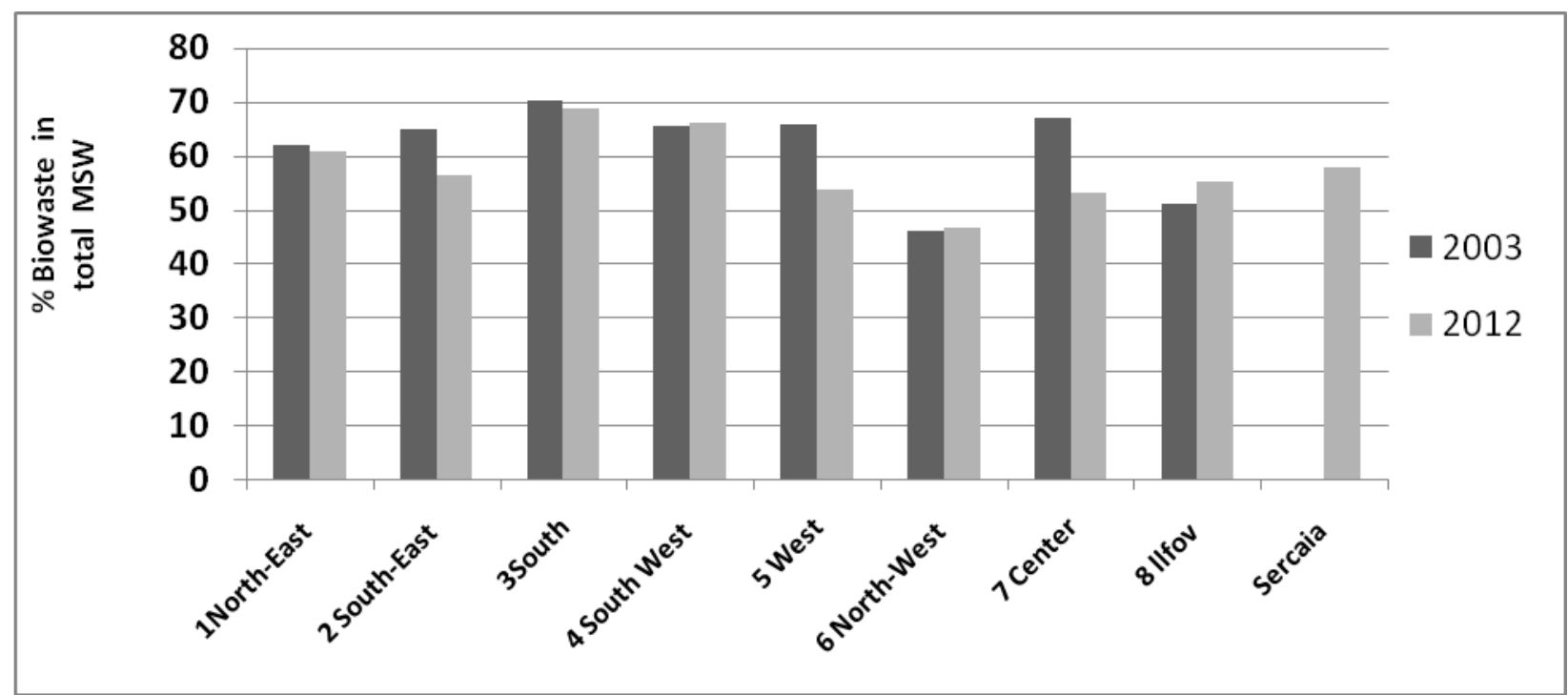

Fig. 1. The share of biowaste (\%) in total rural MSW at NUTS2 regions (1-8) and Sercaia commune used to calculate the $\mathrm{Q}_{\mathrm{bwu}}$ (Source: RWMP 2006, Ciuta et al. 2015)

The biowaste has a significant role in the total composition of MSW stream and the only NorthWest region has values below $50 \%$, which highlights the great potential for the recovery process through composting avoiding the landfill of waste or illegal dumping practices across rural areas.

\subsection{Scenario analysis of biowaste losses}

The local environmental reports stipulate that most of the biowaste of MSW (as food waste, garden and park fractions) is used as home composting and animal feed in rural areas, but no quantitative data are provided. This paper aims to translate such qualitative assertions into quantitative assessments in order to outline the role of home composting (HC) based upon the following scenarios:

no traditional recovery - all biowaste generated and uncollected by WCS is disposed in wild dumps as a worse-case scenario

$>$ pessimistic - $40 \%$, less than half of biowaste is used for home composting,

$>$ realistic - $70 \%$, most of the biowaste is used in home composting as environmental reports stipulated

$>$ optimistic - $90 \%$, this case is rather specific for remote and small rural settlements with a significant share of organic waste in total MSW.

These scenarios are applied across all Romanian counties (41-“judete") equivalent to NUTS-3 EU regions for 2003 and 2012 in order to reveal the geographical dimension of biowaste losses. The results are mapped using thematic cartography. Based on these scenarios, the biomass recovery/losses and $\mathrm{CO}_{2}$ savings were estimated through home composting as opposite to wild dumpsites. 
The biowaste losses refer to the estimated amounts that are uncontrolled disposed without any formal or traditional recovery, which finally ends in the local environment. The dump is the worst-case option taken into consideration which is still widespread in rural areas emitting GHG's into the atmosphere. The paper also reveals the GHG's loads for virtual scenarios (IF) where the biowaste losses are supposed to be collected by waste operators and to dispose them in conventional landfills or sanitary sites. Such scenarios reveal the impact of waste disposal sites in terms of GHG's values compared to traditional recovery through home composting.

\subsection{The GHG's emissions}

The GHG's values are calculated based on the emission factors of home composting determined by experimental studies from the literature, taking into account the organic fraction of MSW. The home composting process generates between 77 to $220 \mathrm{~kg} \mathrm{CO}_{2}$-eq. $\mathrm{t}^{-1} \mathrm{ww}$ (average 148.5) as a direct contribution (Boldrin et al. 2009). These values are consistent with Adhikari et al. (2013) which reveal specific emission factors, according to the home composting system adopted such as: unmixed ground pile (115 $\mathrm{kg} \mathrm{CO}_{2}$-eq), mixed ground pile (129 $\mathrm{kg} \mathrm{CO}_{2}$-eq); plastic bin (83 $\mathrm{kg} \mathrm{CO}$-eq), wood bin (126 kg CO 2 -eq).

In Romania, the biowaste is generally mixed on the ground (open piles) with other agricultural wastes or manure in order to make the compost. This bio-product is usually used on arable land as backfilling. The use of compost decrease the $\mathrm{GHG}$ emissions -146 to $+17 \mathrm{~kg} \mathrm{CO}$-eq (average - 64.5) as indirect downstream according to Boldrin et al. (2009). On this background, the net flux of GHG emissions (loads and savings) is $64.5 \mathrm{~kg}$. $\mathrm{CO}_{2}$-eq $\mathrm{t}^{-1} \mathrm{ww}_{\text {for }}$ applying home composting in rural Romania based on mixed ground pile system, particularly in 2003. Despite the quality of compost may be lower than a centralized composting system, the home composting has significant environmental benefits compared to wild dump sites which prevailed in rural Romania until 16 July 2009. Such dumps may contribute until 561 to 786 $\mathrm{CO}_{2}$-eq $\mathrm{t}^{-1} \mathrm{ww}$ compared to conventional landfills -71 to $150 \mathrm{CO}_{2}$-eq t ${ }^{-1} \mathrm{ww}$ according to Manfredi et al. (2009). The lower limit of the dump is taken into consideration because such sites are much smaller in rural areas with lower wastes disposed than those in urban areas. For conventional landfills, the upper limit found by Manfredi et al.(2009) is considered in this analysis $\left(150 \mathrm{~kg}\right.$. $\mathrm{CO}_{2}$-eq t$\left.{ }^{-1} \mathrm{ww}\right)$ due to the high share of the biowaste fraction in the total mixed MSW stream from Romania. Comparative analysis between the dumps and conventional landfills (often non-compliant with the EU Landfill Directive) is performed for 2003 as the most used waste management options in that period. Sanitary landfills with extensive gas utilization (EGU) are used as a virtual scenario for 2012. The direct GHG's emissions are -71 to $150 \mathrm{~kg}$. $\mathrm{CO}_{2}$-eq t${ }^{-1} \mathrm{ww}$ (average 79) and indirect downstream savings $-5-140 \mathrm{~kg}$. $\mathrm{CO}_{2}$-eq t${ }^{-1} \mathrm{ww}$

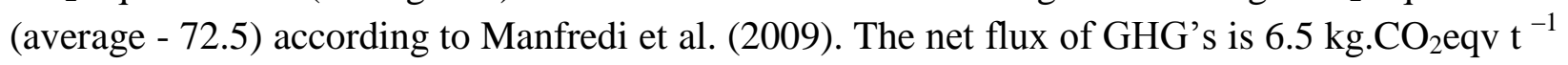
ww. The paper examines the role of plastic bins in the home composting process as a reliable alternative compared to open piles technique in 2012. 
Adhikari et al. (2013) stipulated an emission factor of $83 \mathrm{~kg} \mathrm{CO}_{2}$-eq t$~^{-1}$ ww based on the plastic bin. The net flux of GHG's is $18.5 \mathrm{~kg} \mathrm{CO}_{2}$-eq t ${ }^{-1}$ taking into consideration the indirect downstream (-64.5). These scenarios point out the environmental loads and savings of GHG's and highlight the role of home composting in this matter.

\section{Results}

The poor coverage of waste collection services in Romanian rural areas reflects the high amounts of biowaste generated by population and uncollected by WCS, as depicted in Fig. 2.

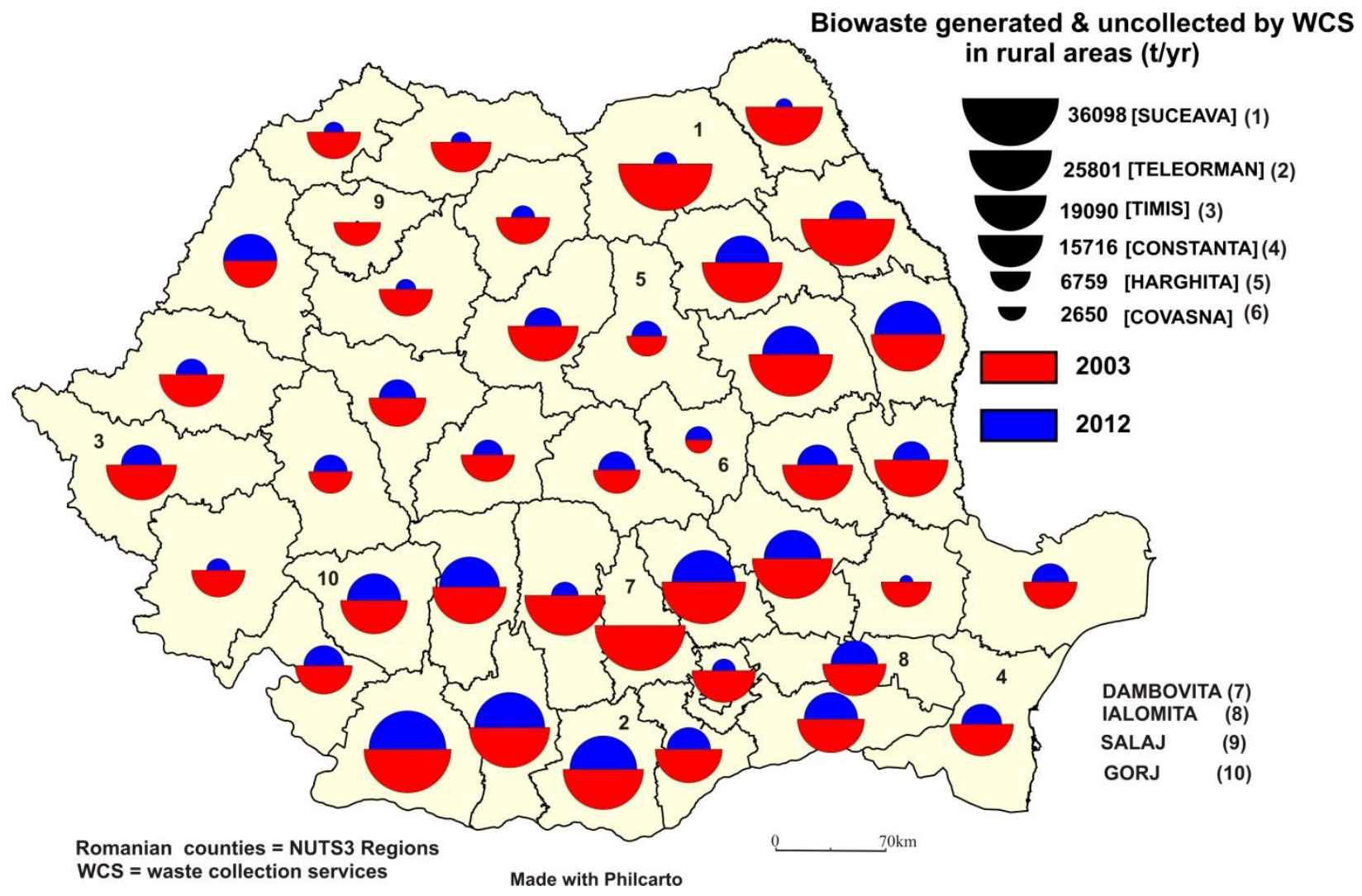

Fig.2. Biowaste uncollected by WCS in rural areas (half circles indicate the amounts of biowaste per yr : 2003 vs 2012)

These amounts also represent the biowaste losses in the worst-case scenario where home composting is not performed. Rural waste management sector is almost completely neglected in 2003. Large amounts of biowaste are generated in North-East, South, South-West and West regions. These rural regions are important agricultural areas. The role of home composting may play a key-role in order to recover the biowaste as compost. There are major disparities at the county level between the largest amounts of biowaste generated and uncollected (eg. Suceava$36 \mathrm{kt}$ ) and the lowest values (Covasna-2.65 kt). 
Such difference is explained by demographic discrepancies between these counties and due to the various waste collection coverage rates. The enforcement of EU Landfill Directive 1998/31 through Government Decision nr. 345/2005 obliged the rural municipalities to closure the wild dumps until 16 July 2009 (Mihai, 2015). This deadline does not solve the rural waste management issue. There are still $3.8 \mathrm{M}$ people from rural areas without access to reliable waste management services in 2012. This population generates a significant amount of biowaste (294.42 kt) which is not treated by the formal sector as in southern Romania (Gorj, Valcea, Dolj, Olt, Telorman, Giurgiu, Calarasi counties), the eastern part of the country (Bacau, Neamt, Vaslui counties) or Western Romania (Bihor and Timis counties). On the other hand, the expansion of waste collection services in 2012 is almost complete in rural areas of Salaj, Braila counties where biowaste losses are reduced to $0.018 \mathrm{kt}$ and $0.527 \mathrm{kt}$. Rural areas of Dambovita county are fully covered by waste collection services and biowaste losses are null in this case. The biowaste is recovered as compost and used on arable land decreasing the net flux of GHG's. The Table 1 shows the significant impact of home composting related to other waste disposal options. In the worst case scenario, almost $1 \mathrm{Mt}$ of biowaste uncollected by waste operators are disposed in wild dumps $\left(\mathrm{Q}_{\mathrm{bwu}} 2003+\mathrm{Q}_{\mathrm{bwu}} 2012\right.$ losses) generating the emission of almost $584 \mathrm{ktCO}_{2} \mathrm{eq}$.

If these wastes had been collected and disposed in conventional landfills the GHG's would have been mitigated to $156.76 \mathrm{ktCO}_{2}$ eq. Home composting even through open pile technique (hc_op) is far more desirable in terms of GHG's emissions than the landfill of waste $\left(26.89 \mathrm{ktCO}_{2} \mathrm{eq}\right)$ if $\mathrm{hc}=40 \%$ and $47 \mathrm{ktCO}_{2} \mathrm{eq}$ if $\mathrm{hc}=70 \%$ ). The amount of $\mathrm{CO}_{2}$-eq data for waste disposal options (dumps and landfills) is calculated based on biowaste losses (2003 and 2012). There are significant differences between open pile and plastic bin systems (hc_pb) in 2012 in terms of GHG's loads across pessimistic, realistic and optimistic scenarios.

The new regional waste management systems must support the individual composting process in rural areas. Plastic bins must replace the open piles techniques for a better environmental protection and control of the composting procedure which will lead to better results in terms of GHGs loads as shown in Table 1.

Pessimistic scenario reveals the biowaste losses (625.28 kt) and GHG's loads in the case the home composting is used less than half of rural residents in 2003 and 2012. This scenario is susceptible rather to the mountainous regions where rural communities have less access to arable lands due to the restrictive geographical conditions. Plain and hill regions are important agricultural areas in Romania, where home composting may be used at widespread scale. Environmental authorities argue that most of the biowaste is used in the home composting process or as animal feed but no quantitative data are provided. 
Table 1

Biowaste losses and loads of GHG's on different scenarios of home composting at national level

\begin{tabular}{cccccc} 
Bio-waste losses / Scenario & Measure units & Worse-case & Pessimistic & Realistic & Optimistic \\
\hline Qbwu_2003 & $\mathrm{Mt}$ & $747,723.28$ & $299,089.31$ & $523,406.29$ & $672,950.95$ \\
Qbw_losses_2003 & $\mathrm{Mt}$ & $747,723.28$ & $448,633.97$ & $224,316.98$ & $74,772.33$ \\
Dumps_2003 & $\mathrm{ktCO}_{2} \mathrm{eq}$ & 419.47 & 251.68 & 125.84 & 41.95 \\
Landfills(IF)_2003 & $\mathrm{ktCO}_{2} \mathrm{eq}$ & 112.16 & 67.30 & 33.65 & 11.22 \\
Qbwu_2012 & $\mathrm{Mt}$ & $294,421.59$ & $117,768.63$ & $206,095.11$ & $264,979.43$ \\
Qbw_losses_2012 & $\mathrm{Mt}$ & $294,421.59$ & $176,652.95$ & $88,326.48$ & $29,442.16$ \\
Dumps_2012 & $\mathrm{ktCO}_{2} \mathrm{eq}$ & 165.17 & 99.10 & 49.55 & 16.52 \\
Landfills (IF)_2012 & $\mathrm{ktCO}_{2} \mathrm{eq}$ & 44.16 & 26.50 & 13.25 & 4.42 \\
Sanitary Landfills EGU & $\mathrm{ktCO}_{2} \mathrm{eq}$ & 1.91 & 1.15 & 0.57 & 0.19 \\
(IF)_2012 & & & & & \\
Home composting & & & & & \\
HC_op_2003 & $\mathrm{ktCO}_{2} \mathrm{eq}$ & & 7.60 & 33.76 & 43.41 \\
HC_op_2012 & $\mathrm{ktCO}_{2} \mathrm{eq}$ & & 2.18 & 3.81 & 4.09 \\
HC_pb_2012 & $\mathrm{ktCO}_{2} \mathrm{eq}$ & & & & 4.90 \\
\hline
\end{tabular}

Qbw= amounts of biowaste ; Qbwu- biowaste uncollected; Landfilles EFG = landfills equipped with extensive gas utilization; HC_op - home composting in open piles ; HC_pb - home composting in plastic bins

The "realistic scenario " considers that $70 \%$ of biowaste uncollected is used for individual composting purposes. Same weighting was attributed to the household recovery of biowaste by Mihai (2012), in order to estimate the amount of household waste uncontrolled disposed at rural municipal level (commune). As a concrete example, the EPA Buzau (2014) stipulates in the environmental report that most of the rural municipalities practice individual composting of biowaste (fraction of MSW) with manure, but these quantities cannot be estimated. This paper could fill this gap, thus, Buzau county used for home composting $17.45 \mathrm{kt}$ of biowaste uncollected in 2003 and $9.35 \mathrm{kt}$ in 2012 based on the "realistic scenario". The rural waste collection coverage has increased in this county from $1.2 \%$ in 2003 to $52 \%$ in 2012.

Any home composting method performed in rural areas is preferable than dumps or even conventional landfills. In terms of GHG's emissions the alternative of sanitary landfills equipped with extensive biogas collection has better results, but these investments are expensive and fits better in large urban areas. Table 1 shows the lowest GHG's values in the case of sanitary landfills with extensive gas utilization (EGU) across pessimistic (1.15 $\mathrm{ktCO}_{2} \mathrm{eq}$ ) and realistic scenarios $\left(0.57 \mathrm{ktCO}_{2} \mathrm{eq}\right)$. Some of the urban landfills need to be upgraded with such facilities in order to comply with the EU requirements. Sparse settlements of rural regions must improve the home composting procedure in order to avoid the landfill of biowaste.

The "realistic scenario" shows the crucial role of home composting in the recovery process of rural biowaste in the context of poor waste management services. From Fig. 3. there is evidence that the composting in plastic bins has better results than open piles in terms of GHG's savings across Romanian counties. According to "realistic" scenario, home composting in open piles generates $13.29 \mathrm{ktCO}_{2} \mathrm{eq}$ and plastic bins only $3.81 \mathrm{ktCO}_{2} \mathrm{eq}$. 
Despite the sanitary landfills with extensive gas utilization have slightly better results regarding the loads of GHG's, the home composting is more viable in rural areas taking into account the economical (cost-efficient), social and environmental benefits. The optimistic scenario where home composting reuse $90 \%$ of biowaste (uncollected by WCS) is specific rather remote rural settlements with low population densities as suggested by Bernardes and Günther (2014).

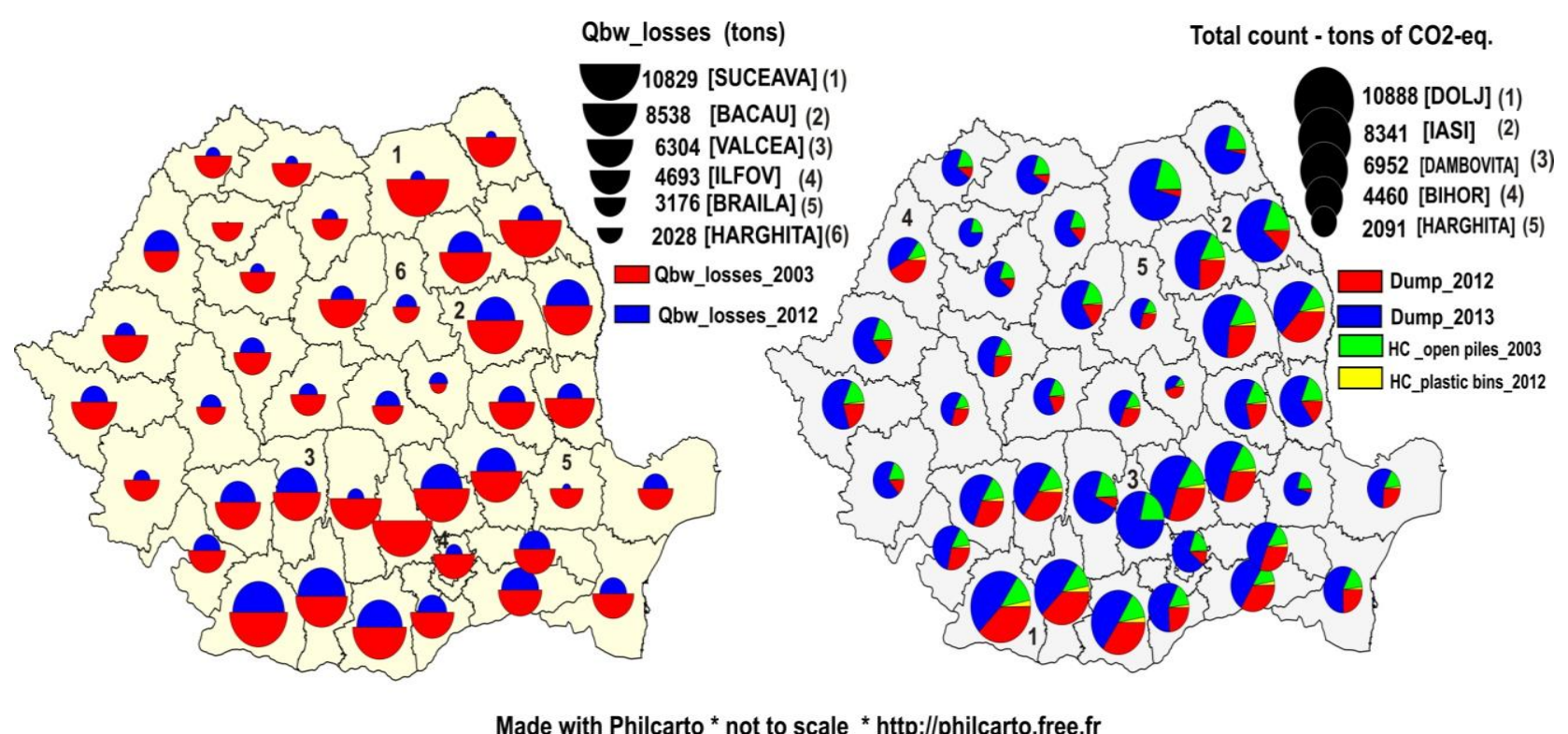

Fig. 3. The biowaste losses and GHG's emission based on realistic scenario 


\section{Discussions}

\subsection{Biowaste management in pre-accession period (2003-2006)}

A comparative analysis of pre-accession period (2003), when waste collection services were barely encountered in rural areas (5.66 \% of the rural population served), and post-accession period (2012) point out the gaps, improvements and regional disparities in the municipal waste management sector. Large amounts of biowaste $(747.72 \mathrm{kt})$ were not collected by waste operators in 2003. These wastes generated $165.17 \mathrm{ktCO}_{2} \mathrm{eq}$ in the worst-case scenario where home composting is not performed. Realistic scenario reveals that home composting using open piles techniques generates much lower emissions (33.76 $\mathrm{ktCO}_{2} \mathrm{eq}$ ) than wild dumps (125.84 $\mathrm{ktCO}_{2} \mathrm{eq}$ ). In 2003, traditional recovery of biowaste at household level had more benefits for the environment than those collected and disposed by waste operators in non-compliant landfills without gas-recovery installations or locate treatment facilities. Mixed waste collection prevailed in 2003, the separate collection was only $1.82 \%$ and most of the biowaste collected as residual waste by waste operators (public or private) were sent to 251 non-compliant landfills. Recycling and treatment rate of MSW was $3.11 \%$ of total MSW collected (635.33 kt). Most of the biowaste collected by waste operators is lost through non-compliant landfills without energy recovery such as biogas. The amount of biowaste separately collected in 2004 is only $5.9 \mathrm{kt}$ out of 2,486.5 kt estimated by environmental authorities. The poor waste management facilities from rural areas highlight the key role of home composting in order to avoid the improper waste disposal practices. Pessimistic scenario reveals $448.63 \mathrm{kt}$ of biowaste losses which end up in dumps emitting $251.68 \mathrm{ktCO}_{2 \text { eqv }}$ compared to realistic scenario $\left(224.31 \mathrm{kt}-125.84 \mathrm{ktCO}_{2 \text { eqv }}\right)$ or optimistic scenario $\left(74.77 \mathrm{kt}-41.95 \mathrm{ktCO}_{2 \mathrm{eqv}}\right)$. Home composting through open piles techniques has been a better option than the dumping of biowaste on uncontrolled disposal sites in the context of no waste collection services and the lack of centralized composting facilities during the pre-accession period.

\subsection{Biowaste management in the Post Accession period (2007- 2014)}

Significant improvements in the municipal waste sector have been made since 2003 taking into considerations: EU legislation, national, regional and local waste management plans, development of waste management infrastructure through pre-adhesion (ISPA, Phare) and postadhesion funds (SOP-ENV), emerging of waste and recycling operators and so. Despite these improvements, there are still major gaps between urban and rural areas. Rural waste management is a key challenge of Romanian environmental policy where only $59 \%$ of the population was served by waste collection services in 2011. On this background, $294.42 \mathrm{kt}$ of biowaste were not collected by waste operators in 2012. In the worst-case scenario, these biowastes disposed in wild dumps generate $165.17 \mathrm{ktCO}_{2} \mathrm{eq}$. The home composting reduces the GHG's emissions (13.29 $\left.\mathrm{ktCO}_{2} \mathrm{eq}\right)$. 
Wild dumps or on-site burning sites have also occurred in rural island communities of Greece, where home composting and animal feed reduce the amount of biowaste disposed (Panaretou et al., 2016). The food waste fraction may be mixed with manure and other agricultural wastes in order to make compost. The large open piles may be a local organic pollution source for surroundings such as nitrates or ammonia if these sites are directly located on land. The use of plastic bins will avoid direct contact of biowaste fraction with the land. The best results in terms of GHG's emissions are provided by home composting in plastic bins $\left(3.81 \mathrm{ktCO}_{2} \mathrm{eqv}\right)$ as outlined by Fig. 3 across Romanian counties.

In Romania, there are 70 composting platforms and plants covering urban and rural areas in 2012 and another 50 facilities were under construction (NEPA, 2013). Centralized composting plants and anaerobic digestion plants firstly require an accurate source-separated collection of biodegradable waste (population, economic agents) which was barely implemented in 2012. Composting and digestion reached only $1 \mathrm{~kg}$.capita. $\mathrm{yr}^{-1}$ as a MSW treatment option in Romania during 2011-2013 compared to EU27 average of 71 kg.capita.yr ${ }^{-1}$ (Gavrilescu and Teodosiu, 2016). The amount of biowaste separately collected was only $30.6 \mathrm{kt}$ in 2011 mainly from urban areas. Ingleziakis et al.(2016) reveal that current composting plants capacity of NorthEast Region $(29,400 \mathrm{t} /$ year) is not sufficient in the case of a full source-separated of biowaste fraction across the six counties of the region (urban $\&$ rural areas). Small composting platforms

(50 t.yr ${ }^{-1}$ ) were built in rural areas as follows : 15 sites across 7 communes in Calarasi county ;24 sites across 24 communes in Ialomita county. Such initiatives should be further developed, especially in such important agricultural areas, because the amount of biowaste uncollected in 2012 is $17.54 \mathrm{kt}$ in Calarasi and $15.77 \mathrm{kt}$ in Ialomita county. The population should be aware of the importance of the correct separation of biowaste fraction across urban areas (high purity) and the role of home composting in rural areas.

\subsection{Future perspectives in biowaste management}

The high share of the biodegradable fraction (50-60\%) moisture content $(50 \%)$ and lower caloric values of MSW (less than $8,400 \mathrm{~kJ} / \mathrm{kg}$ ) in Romania (NEPA,2009) reflect a great potential for the composting process in urban and rural areas. The content of heavy metals in MSW fraction is much lower than EU limits which may increase the quality of compost obtained from biowaste fraction (Ciuta et al. 2015). County councils rely on EU funds in order to improve the existing infrastructure in rural regions and to upgrade them to current standards. Biowaste may be used to produce bioenergy such as biogas, but these facilities, which were initially focused on farm waste and sludge from municipal wastewater treatment plants, have decreased their activity since 90's due to the lack of investments and poor maintenance (Mateescu et al., 2008). Composting plants and biogas installations require major investments and such funds were no available during the transition period since the collapse of socialism. 
Home composting plays a key role in rural areas in order to divert the biowaste from wild dumps or landfills even for regions which are not covered by waste collection services. Comparative analysis between 2003 and 2012 shows large amounts of biowaste uncollected by the formal sector, particularly across important agricultural counties (northeast, east, south, and southwest). The home composting through open piles mitigates GHG's emissions (33.76 $\left.\mathrm{ktCO}_{2} \mathrm{eq}\right)$ compared to dumps $\left(125.84 \mathrm{ktCO}_{2} \mathrm{eq}\right)$ in 2003. The paper points out that the use of plastic bins will increase the control of the composting procedure with better results in compost quality and overall GHG's savings in 2012. The improvement of home composting must further develop in rural areas by applying best practices available. According to Vucijak et al. (2016), the home composting in rural areas combined with a source-separate collection of recyclables in urban areas and a regional sanitary landfill seems to have higher economic and environmental benefits at the municipal level in the Balkan region. A good cooperation and proper information related to the source separation scheme lead to high recovery levels of biowaste in rural Greek municipalities (Panaretou et al., 2016). Source-separate collection and recycling activities are emerging in some Romanian rural areas (Mihai, 2016). The new waste management strategy for 2014-2020 period recognize the key role of home composting in such matter (Government Decision, 2013). The main issue is the quality of compost resulted in households used for backfilling of arable land. The rural population may not follow strict regulations as compost resulted in specific plants. This option is more affordable and convenient for rural regions, but the methods should be improved in order to obtain a higher quality of compost and to increase the net $\mathrm{CO}_{2}$ savings. Significant cost-reduction of the composting process (17 to $84 \%$ ) may be achieved in developing countries if critical qualitative parameters are properly monitored (VanFan, 2016). Good compost quality may be obtained through home composting or vermicomposting on a small scale (Lleó et al. 2013). The compost should be made of kitchen residues (fruits, vegetables, used coffee grounds) and garden waste (weeds, branches, dry leaves, plant debris) in order to provide an equilibrium between materials rich in carbon or nitrate. The meat, bones, fish are perishable materials, ashes from the stove, inorganic materials should be avoided in the home processing process.

Many local authorities in the UK support home composting through the provision of advice and/or subsidized or free composting bins (Burnely, 2014). Guidelines regarding how to perform the home composting in containers (bins) must be shared with the local population. This paper outlines that plastic bins should replace the open-pile technique of home composting as they maintain the control of temperature and humidity and they make it possible to:

- easier perform the aeration process;

- avoid the dispersion of waste;

- $\quad$ protect compost from other insects and rodents

Special plastic bins should be provided by local municipalities with concrete guidelines how to obtain a qualitative compost at the household level.

Taking the instance case of Romania, such guidelines are available at http://www.twinningwaste-bacau.ro/waste-1/ce-putem-face/materialele/manual-pentru-obtinerea-compostului-in- 
gospodarii as part of an EU project "Twinning Domestic Waste Management" where regional authorities from Romania (North-East Region) Spain (Galicia) and the Netherlands share their experiences in the field. New county integrated waste management systems involved private and public waste operators which serve urban and rural municipalities. Inter-municipal associations are developing in order to provide reliable waste management services at regional scale. Rural municipalities must be fully covered by separate waste collection services in the next following years in order to achieve high rates in terms of recycling and composting activities.

\section{Conclusions}

This paper outlines the crucial role of home composting in order to combat the biowaste losses through waste dumping across rural Romania in the last decade (2003 vs 2012).

A quantitative assessment of these losses is performed based on four scenarios analysis. The worst-case scenario reveals the loads of GHG's emission emitted by wild dumps if home composting is not performed (419.47 $\mathrm{ktCO}_{2} \mathrm{eq}$ in 2003 and $165.17 \mathrm{ktCO}_{2} \mathrm{eq}$ in 2012). The pessimistic (hc $=40 \%)$, realistic $(\mathrm{hc}=70)$ and optimistic $(90 \%)$ scenarios show the role of home composting in diverting the biowaste fraction from illegal waste dumping and GHG's savings even if the rural population is not served by waste operators. The expansion of waste collection coverage across rural areas mitigated the amounts of biowaste generated and uncollected from $747.72 \mathrm{kt}$ in 2003 to $294.42 \mathrm{kt}$ in 2012. The data are broken down at county level (NUTS3 region) in order to reveal the geographical disparities across rural Romania. The paper reveals that biowaste through home composting may play a key role towards a sustainable rural development based on low-carbon society. Realistic scenario (2012) shows that home composting in plastic bins has better results in terms of $\mathrm{GHG}$ emissions $\left(3.81 \mathrm{ktCO}_{2} \mathrm{eq}\right)$ than composting performed in open piles (13.29 ktCO2_eqv) or if biowaste is disposed in conventional landfills (13.25 $\left.\mathrm{ktCO}_{2} \mathrm{eq}\right)$. Home composting should be a widespread waste management option across important agricultural regions of the country such as North-East, South-East, South-Muntenia and South-West Oltenia. Home composting opportunities across rural regions must be further analyzed in transition economies. The good practice of composting process among rural residents is imperative in order to obtain a cost-efficient and qualitative compost. Other benefits of home composting such as replacement of chemical fertilizer, resource conservation, peat substitution, improve soil fertility and crop health should be outlined in future studies. A sound biowaste management in rural Romania should be implemented to support a reliable development of bioeconomy as promoted by the EU. 


\section{Acknowledgements}

The paper is the result of a fully independent research without any funding.

\section{References:}

Adhikari, B.K., Trémier, A., Barrington, S., Martinez J., Daumoin M., 2013. Gas emissions as influenced by home composting system configuration. Journal of Environmental Management. 116,163-171

Andersen, J.K., Boldrin, A., Christensen, T.H., Scheutz, C., 2010. Greenhouse gas emissions from home composting of organic household waste. Waste Management, 30, 2475-2482.

Barekova, A., Halajova, D., Barek, V., Halaj, P., 2013. Representation of biodegradable waste in municipal solid waste in rural landscape. 13th SGEM GeoConference on Ecology, Economics, Education And Legislation, June 16-22, 2013 Conference Proceedings,1, 833 - 838. doi:10.5593/sgem2013/be5.v1/s20.109

Bernardes, C., Günther, W.M.R., 2014. Generation of Domestic Solid Waste in Rural Areas: Case Study of Remote Communities in the Brazilian Amazon. Human Ecology. 42,(4), 617-623. doi: 10.1007/s10745-014-9679z

de Besi, M., McCormick, K., 2015. Towards a bioeconomy in Europe: national, regional and industrial strategies. Sustainability, 7, 10461-10478. doi:10.3390/su70810461

Blok, V., Long, T. B., Gaziulusoy, A.I., Ciliz, N., Lozano, R., Huisingh, D., Csutora M., Boks, C., 2015. From best practices to bridges for a more sustainable future: advances and challenges in the transition to global sustainable production and consumption Introduction to the ERSCP stream of the Special volume. Journal of Cleaner Production 108. 19-30

Boldrin, A., Andersen, J.K., Møller, J., Christensen T.H. 2009. Composting and compost utilization: accounting of greenhouse gases and global warming contributions. Waste Management \& Research. 27 (8), 800-812 . doi: 10.1177/0734242X09345275

Burnley, S. (ed). 2014. Section 1: Wastes Basics in Solid Wastes Management. In: Solid Wastes Management John Wiley \& Sons, Ltd, Chichester, UK. doi: 10.1002/9781118863923.ch1

Ciubota-Rosie C., Gavrilescu, M., Macoveanu, M., 2008. Biomass - an important renewable source of energy in Romania . Environmental Engineering and Management Journal. 7 (5), 559568

Ciuta, S., Apostol, T., Rusu, V., 2015. Urban and Rural MSW Stream Characterization for Separate Collection Improvement .Sustainability. 7, 916-931, doi:10.3390/su7010916

Colón, J., Martínez-Blanco, J., Gabarrell, X., Artola, A., Sánchez, A., Rieradevall, J., Font, X., 2010. Environmental assessment of home composting. Resources, Conservation and Recycling 54, 893-904

Ermolaev, E., Sundberg, C., Pell, M., Jonsson, H. 2014. Greenhouse gas emission from home composting in practice. Bioresource Technology. 151, 174-182. European Commission. 2012. Innovating for Sustainable Growth: A Bioeconomy for Europe. Publication Office of the European Office: Luxembourg 
Gavrilescu-Cailean, D., Teodosiu, C., 2016 An assessment of the Romanian solid waste management system based on sustainable development indicators . Sustainable Production and Consumption. http://dx.doi.org/10.1016/j.spc.2016.07.004

Government Decision no. 870/ 2013. National Waste Management Strategy in Romania 20142020

Havukainen, J., Zavarauskas, K., Denafas G., Luoranen, M., Kahiluoto, H., Kuisma, M., Horttanainen, M., 2012. Potential of energy and nutrient recovery from biodegradable waste by co-treatment in Lithuania. Waste Management and Research. 30(2), 181-189 doi: 10.1177/0734242X11427945

Horsák, Z., Hřebíček, J. 2014. Biodegradable Waste Management in the Czech Republic. A Proposal for Improvement . Pol. J. Environ. Stud. 23 (6), 2019-2025

Inglezakis, V., Ambăruş M., Ardeleanu N., Moustakas K., Loizidou M. 2016. Waste management in Romania: current data and application of a decision support tool. Environmental Engineering and Management Journal, 15, (3), 511-519

Landfill Directive, 1999. Council directive 1999/31/EC of 26 April 1999 on the landfill of waste. Official Journal of the European Communities, I. 182/1, Office for official publications of the European Communities, 2, rue Mercier, L e 2985 Luxembourg.

Lim, SL, Lee, LH. Wu, TY., 2016. Sustainability of using composting and vermicomposting technologies for organic solid waste biotransformation: Recent overview, greenhouse gases emissions and economic analysis. Journal of Cleaner Production. 111, 262-278 doi: 10.1016/j.jclepro.2015.08.083.

Lleó, T., Albacete, E., Barrena, R., Font, X., Artola, A., Sánchez, A., 2013. Home and vermicomposting as sustainable options for boost management. Journal of Cleaner Production 47, $70-76$

Manfredi, S., Tonini, D., Christensen, T.H., Scharff, H., 2009. Landfilling of waste: accounting of greenhouse gases and global warming contributions. Waste Management \& Research. 27(8), 825-836. doi: 10.1177/0734242x09348529

Mateescu, C., Băran, G, Băbuţanu, C.A., 2008. Opportunities and barriers for development of biogas technologies in Romania. Environmental Engineering and Management Journal. 7 (5), 603-607

Ministry of Economy and Commerce and Bussiness Sector, 2010. Master Plan for biomass ( in Romanian) Partners : NL Agency (Netherlands) Enero (Romania) Available at : http://www.minind.ro/biomasa/Plan_de_Actiune_pentru_Biomasa.pdf (Accessed 17.05.2015)

Mihai, F.C. 2016. East European recycling societies: The first steps of rural communities in Neamt County, Romania. In: Girotto F. (ed.) A Glance at the World. Waste Management. 56, IIII http://dx.doi.org/10.1016/S0956-053X(16)30465-2

Mihai, F.C. 2015. Spatial distribution of rural dumpsites parameters in Romania. Bollettino della Associazione Italiana di Cartografia, 154, 93-101, doi: 10.13137/2282-472x/11830

Mihai, F.C. 2012, Improper household waste disposal in rural territory. Case Study: Neamt County, Romania. Bulletin USAMV Agriculture, 69(2),15-20,

National Environment Protection Agency (NEPA), 2013. The State of the Environment report in 2012

National Environment Protection Agency (NEPA), 2009. The State of the Environment report in 2008 
Ortner, M.E., Müller, W., Bockreis, A., 2013. The greenhouse gas and energy balance of different treatment concepts for bio-waste. Waste Management \& Research. 31(10) Supplement 46-55 doi: 10.1177/0734242x 13500518

Panaretou, V., Malamis, D., Papadaskalopoulou, C., Sotiropoulos, A. Valta, K., Margaritis M., Plevri, A., Moustakas, K., Loizidou M., 2016. Implementation and Evaluation of an Integrated Management Scheme for MSW in Selected Communities in Tinos Island, Greece.

Waste Biomass Valor. doi:10.1007/s12649-016-9632-z

Scarlat, N., Dallemand, J.F., Monforti-Ferrario, F., Nita, V., 2015. The role of biomass

and bioenergy in a future bioeconomy: policies and facts. Environ. Dev. 15, 3-34. doi:10.1016/j.envdev.2015.03.006

Scarlat, N., Blujdea, V., Dallemand, J.F., 2011. Assessment of the availability of agricultural and forest residues for bioenergy production in Romania . Biomass and Bioenergy. 35, 1995- 20 05

Smith, S.R., Jasim, S. 2009. Small-scale home composting of biodegradable household waste: overview of key results from a 3-year research programme in West London. Waste Management \& Research. 27, 941-950, doi: 10.1177/0734242X09103828

Stanic-Maruna I., Fellner, J., 2012. Solid waste management in Croatia in response to the European Landfill Directive. Waste Management \& Research. 30(8), 825-838 doi: $10.1177 / 0734242 \times 12444897$

Van Fan, Y., Lee, C.T., Klemeš, J.J. et al. (2016). Economic assessment system towards sustainable composting quality in the developing countries. Clean Techn Environ Policy doi:10.1007/s10098-016-1209-9.

Vucijak, B., Kurtagić SM, Silajdžić, I. 2016. Multicriteria decision making in selecting best solid waste management scenario: a municipal case study from Bosnia and Herzegovina. Journal of Cleaner Production.130, 166-174 http://dx.doi.org/10.1016/j.jclepro.2015.11.030

Wójcik, G., Jacyno, M., Korkosz-Gebska, J., Krasuska., E., Oniszk-Popławska A., Trebacz, D., 2014. Location selection analysis for biological treatment plants for municipal waste.

Journal of Power Technologies. 94 (1), 1-19

Wubben, E.F.M., Runge, N.A., Blok, V. 2012. From Waste to Profit. An interorganisational perspecive on drivers for biomass valorization. Journal of Chain and Network Science. 12 (3), 261-272) 